August 2012

\title{
The Question of an Armenian Revolution and the Radicalization of the Committee of Union and Progress toward the Armenian Genocide
}

Wolfgang Gust

\section{Recommended Citation}

Gust, Wolfgang (2012) "The Question of an Armenian Revolution and the Radicalization of the Committee of Union and Progress toward the Armenian Genocide," Genocide Studies and Prevention: An International Journal: Vol. 7: Iss. 2: Article 8.

DOI: $10.3138 /$ gsp.7.2/3.251

Available at: https://digitalcommons.usf.edu/gsp/vol7/iss2/8

This Articles is brought to you for free and open access by the Open Access Journals at Digital Commons @ University of South Florida. It has been accepted for inclusion in Genocide Studies and Prevention: An International Journal by an authorized editor of Digital Commons @ University of South Florida. For more information, please contact digitalcommons@usf.edu. 


\title{
The Question of an Armenian Revolution and the Radicalization of the Committee of Union and Progress toward the Armenian Genocide
}

\author{
Wolfgang Gust \\ Hamburg, Germany
}

\begin{abstract}
Hilmar Kaiser, one of the first German historians to work on the Armenian Genocide and one who has often written about it as a historical fact, is now trying to dilute that history. In his latest article, which consciously avoids use of the term genocide, Kaiser seeks to portray Mehmed Djemal Pasha, a member of the Young Turk triumvirate ruling the Ottoman Empire during World War I, as an individual resisting the genocidal policies of his co-conspirators within the Committee of Union and Progress. Kaiser claims to employ Ottoman documents to demonstrate that the initial intention of the Turkish government was to relocate the Ottoman Armenians for military reasons, although he admits that they posed no imminent danger to the state. Kaiser indicates that the first "relocations" of Armenians took place in areas controlled by Djemal and were initiated by him, then goes on to claim that even though the infamous death camp of Deir-es-Zor was located within his sphere of power, he, in reality, protected the Armenians. However, facts showing the extent of the genocide have been overlooked. This article will use archival documents from the Foreign Office of the German Empire, the Ottoman Empire's wartime ally, to demonstrate the shortcomings of Kaiser's evidence and arguments.
\end{abstract}

Key words: Armenian Genocide, Djemal, Young Turks, Kaiser, German archives, Ottoman archives, German compliance, Zeitun, deportations

Hilmar Kaiser's latest publication, "Regional Resistance to Central Government Policies: Ahmed Djemal Pasha, the Governors of Aleppo, and Armenian Deportees in the Spring and Summer of 1915,"1 states that there never was a national Armenian revolution that seriously threatened the Ottoman Empire. This, however, is the key theory behind the main argument that previously denied the Armenian Genocide, a theory that was adopted at that time by the German allies of the Young Turk killers, against the better knowledge of their own observers on site who vehemently contradicted this, but were unable to assert themselves against their superiors.

Kaiser restricts his statements mainly to the sphere of control of the Fourth Army, which was commanded by Mehmed Djemal Pasha. This sphere ranged from Zeitun, the Armenian stronghold in the north, to the city of Urfa in the east, and included Syria and Palestine, as well as Arabia as far as Mecca and Medina.

Regarding the Armenians in this region, the German vice-consul of Alexandretta (Iskenderun), Hermann Hoffmann-Fölkersamb, who was often temporarily in charge of such important consulates in Djemal's area as Aleppo, Damascus, and Haifa, was certain: "I do not believe that they would commit treason." ${ }^{2}$ Furthermore, with regard to the alleged military danger posed by the Armenians, Hoffmann wrote, 
Apart from the case of Van and its adjacent zone, particular caution is called for relative to the charge of a "militarily organized plot." Certain local insurrectionary movements cannot be treated as proof of such. For example, the fact that the revolt in Zeitun cannot be singled out as a case of a conspiracy of that kind, is clearly evidenced in the reports of the Imperial Consulate in Aleppo. The uprising of the Armenians in the region of Suediye [Musa Dagh] (to the south of Alexandretta) was, according to the descriptions even on the part of the Turkish military, not a conspiracy. The recovery of the revolutionaries from Suediye by French warships was also not a long-planned act. This is apparent from the circumstances and the opinions of well-informed Turks. ${ }^{3}$

Kaiser agrees with him, albeit more theoretically, because he justifies the brutal actions of the Turks against the supposed revolutionaries. And after his verbal knockout against those who deny the genocide, he lets them land gently by claiming that Djemal did not carry out any genocidal actions against the Armenians and, therefore, the word genocide should not be included in his article.

Kaiser wants to prove that Djemal attempted to rescue the Armenians from annihilation. This is surprising because not only was the infamous death camp of Deir-es-Zor located within Djemal's sphere of power, but also the desert strip along the Euphrates and especially along the Chabur River, where the surviving Armenians were literally butchered.

Kaiser divides those who have done research on this genocide into two schools of thought: on the one hand, there are those, including Vahakn N. Dadrian and Taner Akçam, who started with the assumption that there was a central plan for eliminating the Armenians; on the other hand, there are others, such as Raymond Kévorkian, who assumed that there was a policy of resettlement that was meant to create a general majority for the Turks or at least the Muslims. Both schools of thought, however, assumed that there was intent to annihilate the Armenians and other Christian minorities, whose fate was, therefore, already settled before the beginning of the war.

Kaiser's theory that originally there was no central plan at all opposes this. He writes,

This article suggests that the notion of a unified body of genocidal conspirators exerting unrestrained control over the entire Ottoman Empire cannot be sustained. . . This regional study will challenge such notions. It claims that Ottoman deportation policies concerning Armenians evolved in 1915 in a concrete historic context and not from a conspiratorial plan waiting to be revealed. ${ }^{4}$

It was only at the end of May 1915, according to Kaiser's conclusion, that the "actual" situation led to the systematic deportation of Armenians from their areas of settlement and a central management was put into place.

With regard to Mehmed Talât, the main person accused, and the Interior Ministry, he writes,

Far from simply imposing its decisions, the ministry quickly met with resistance from Djemal who doubted the wisdom of the central government's policies. . . . The opposition against Talaat's and the ruling [Committee of Union and Progress]'s policy was stronger than has been assumed so far, reaching into the leadership of the party. At its core stood Ahmed Djemal Pasha. ${ }^{5}$ 
Kaiser notes that by

introducing extensive documentation produced by Ottoman provincial and military authorities, the article contextualizes Ottoman central government directives. ... [The] Ottoman officials at the highest level of government had detailed knowledge of the consequences of their decisions. The data also confirms in detail shocking Western consular reports. Thus, the various sources corroborate each other and form a consistent record. ${ }^{6}$

Many of these Western reports (mainly American and German) have meanwhile been published. What new findings does Kaiser now convey based on these internal files? He first describes events that are certainly known. For example,

Teşkilât-1 Mahsusa units were to perform acts of sabotage and stir up rebellions among the local Muslim population. In this connection, the CUP hoped to win the cooperation of the Armenian Revolutionary Federation (ARF), which had branches in both countries. During CUP-ARF negotiations Teşkilât-1 Mahsusa members revealed their secret agenda, but failed to obtain the ARF's cooperation. ${ }^{7}$

Kaiser then goes on to write of the Gulf of Alexandretta (Iskenderun), where the Turks feared naval attacks by the Entente fleet and arrested several Armenians whom, according to Kaiser, they suspected of being in contact with British ships.

Vice-Consul Hoffmann reported the following regarding this episode from the Consulate in Alexandretta: twice, when the English cruiser Doris landed, Armenian soldiers were taken prisoner. "Once, an Armenian sergeant of a group of seven men (equipped with malfunctioning Martinis) in a trench (with no emergency exit) supposedly surrendered by waving a handkerchief." ${ }^{\prime \prime}$ In his article, Hilmar Kaiser now presents the reasons, based on Ottoman files:

In the south, along the Gulf of Alexandretta, Ottoman commanders worried about an allied landing that could cut off the supply lines of the Ottoman armies in Palestine, Mesopotamia, and parts of the eastern front. In Adana province, authorities had apprehended some Armenians who had been in touch with British warships bombarding the coast. The espionage was deemed serious as few troops and hardly any artillery were available to defend the coast. Moreover, Adana provincial authorities had filed worrying reports about the activities of Armenian political parties. The governor now considered the removal of all Armenians from the coast to the interior of the province. Exemplary punishment was to be meted out to those Armenians found guilty in order to serve as a deterrent to others. Talaat approved the governor's proposal for the deportation of the town of Dortyol on March 2, 1915. Moreover, the minister ordered the authorities to eradicate any Armenian revolutionary activity. On March 13, 1915, Djemal specified other measures against a feared Armenian uprising. A number of troops would stay in Adana, while regional commanders would establish courts-martial in Armenian-inhabited areas. Moreover, preparations for the deportation of Armenians from Aleppo province had been authorized. ${ }^{9}$

What Vice-Consul Hoffmann regarded as a trifle and, therefore, what the consulate ignored, was sufficient reason for Talât, Djemal, and the rest to initiate the genocide. According to Kaiser, courts martial were established for civilians, Armenians hanged 
merely as a deterrent and driven from their native areas, not because of anything they had done that was proven, but solely on the basis of suspicions. Vice-Consul Hoffmann reported at the time on this matter, using Dortyol as an example, "Out of Fakhri Pasha's own mouth I heard that they will not shy away from violence and even injustices." 10 General Fakhri Pasha was Djemal's military leader in that region.

In other words, internal reports also stated that the main initiator of the first Armenian deportations was the supposed member of the resistance, Djemal Pasha. Kaiser could hardly have begun the defense of his hero in a more curious manner, but it becomes even stranger! According to Kaiser, "In this climate . . . Zeitun gained special importance."11 The mountain town of Zeitun, located north of Marash, had been an Armenian stronghold since time immemorial. It had previously defended itself against all of the persecutions against the Armenians. In August 1914, Armenians who were once again called to arms escaped to the mountains and entrenched themselves in a monastery just outside of the town. Kaiser states that "the Muslim population in the region was agitated as it had answered the call." ${ }^{12}$ As a result, this could-and probably was meant tocreate the impression that desertion was a very Armenian type of problem. In actual fact, the deserters in Zeitun also included Turks, and desertion was to become one of the largest problems faced by the Turkish Army. "Today, the number of Turkish deserters is higher than the number of soldiers actually in the army," General Liman von Sanders, the commanding German officer, ascertained at the end of the war. ${ }^{13}$

The events in Zeitun are described in far more detail in the German documents than in Kaiser's article. ${ }^{14}$ For example, Kaiser does not reveal that, with the assistance of the German artillery officer Eberhard Count Wolffskeel von Reichenberg, the monastery the deserters escaped to was destroyed; nor does he mention the request made by the German gunner to prohibit the journey of the German consul in Aleppo Walter Rössler to Zeitun - which the Embassy then did-or the extremely detailed and enlightening report by the Armenian Catholicos of Cilicia on these events. ${ }^{15}$ In particular, Kaiser does not report that, after his investigation in Marash, Rössler did not find any evidence at all why the government should have had a reason for accusing the Armenians in Zeitun of conspiracy. The Armenians were deported simply out of fear (i.e., completely indiscriminately).

According to Kaiser, Djemal ordered the deportation of some families, but then local authorities "demanded that all Armenians should be investigated, including those who were not suspect, on the grounds that they all shared the same mentality." 16 Although the reader does not find out who these "local authorities" are, their attitude does become clear: "The local authorities alleged that Armenians had displaced Muslims in the past. Now Armenian villagers should be deported wholesale and replaced with Muslim settlers." 17 Djemal soothed his conscience by ordering that no innocent Armenian be harmed, but then agreed in practice with the unqualified arguments of the unnamed sources: "The general proposed sending two-thirds of Zeitun's Armenian population to the plains of Konia province. There they would be dispersed and settled among Muslim villagers" because he "thought the time had come to solve the 'Zeitun problem' once and for all," Kaiser reports. ${ }^{18}$ According to German reports, there was no uprising in Zeitun, and the Armenian population worked closely with authorities to turn in deserters. Why, then, in Djemal's (or Kaiser's) view, did a problem have to be solved "once and for all" by finally deporting all of the Armenians? Kaiser gives the following explanation: "This ambitious project went beyond controlling the area and 
aimed at destroying the demographic basis for any possible sustained popular Armenian resistance." 19 However, the governor of Aleppo, Djelal Bey, did not see any reason at all for deporting the Armenians of Zeitun, and had this view placed on record. Djemal arranged that Djelal no longer have jurisdiction over the region around Marash, and therefore Zeitun, so that Djelal could not exert any influence on the deportations. Contrary to Djemal, Djelal was regarded by the Germans-and the Americans-as a real opponent of the Armenian deportations in Cilicia.

Kaiser writes that "by the middle of April 1915, Djemal extended the deportations within the 4th Army's area, arguing that concentrations of Armenians might become dangerous in future"-in other words, pure and unadulterated ethnic cleansing. ${ }^{20}$ The settlement of deported Armenians was, therefore, to be carried out far away from other Armenian communities, but care was to be taken to ensure the safety of the Armenians. Kaiser offers as proof a report by Baron Max von Oppenheim, head of the German Information Service for the Orient, to Chancellor Bethmann Hollweg in Berlin, dated 29 August 1915. This report included five orders by Djemal as enclosures, written in French. Enclosure two, dated 2 April 1915, includes the following extract from Djemal's orders to the commanding chief of the army: "Tout groupement arménien existant dans la zone de la IV. Armée et pouvant être dangereux à l'avenir doit être dispersé" (Any Armenian grouping existing in the zone of the Fourth Army and which could be potentially dangerous for the future must be dispersed). It is worded in a way that anticipates the subsequent national deportation order. However, Enclosure one contains an order issued by Djemal dated 16 March 1915, stating that "le bien et la vie et l'honneur de la population arménienne et musulmane sont sous la sauvegarde du Gouvernement Ottoman. Ils peuvent être convaincus qu'ils ne seront l'objet d'aucune oppression et peuvent vaguer tranquillement à leurs affaires et travaux" (The well-being and life and honor of both the Armenian and Muslim populations are under the protection of the Ottoman Government. They can be convinced that they will not be subject to any oppression and therefore can go about their business and work calmly). ${ }^{21}$

Anyone who has dealt with the Armenian Genocide will rub their eyes in disbelief because it is documented there in black and white that Djemal ordered for both Muslims and Armenians to be treated equally well. He ordered this, but it seems no one followed this order. Strangely, however, Kaiser cites a German source for Djemal's order, while previously he used only Ottoman sources for such orders. The reason is soon discovered: the author of this document is Baron Max von Oppenheim, who was extremely well-known in Germany at that time as a great archaeologist, while, at the same time, being one of the most ambivalent German politicians in the entire "Orient," known by the British only as the "Lying Baron."

Oppenheim described himself as a friend of Djemal's and, therefore, his opinion of what constitutes the typical characteristics of an Armenian is not without interest:

Their proverbial trickiness in business, their addiction to intrigues, their conceit and sense of revolution, but especially the way they constantly sprawl all over their environment and, during the recent past, the way they openly show their hostility towards the Turks.

Oppenheim says that "should the enemy land, the Armenians would join the enemy to form a mutual revolt." According to Oppenheim, "such a landing could be expected foremost just here, at the Gulf of Alexandretta and near Mersina." He warned that 
the consequences in connection with a large Armenian uprising could have been unforeseeable: once it held the passes over the Zeihun, the Djihan, and the Cilician highland, the enemy could have separated Asia Minor and the European part of Turkey from the entire southern and southeastern part of the empire. ${ }^{22}$

Vice-Consul Hoffmann's reply to the report on Oppenheim's fantasies of espionage in the Gulf of Alexandretta was, "I have never heard this accusation, not even from the Turkish Muslim side, although the case is known to me in full detail."23

Kaiser deals with the prophylactic deportations of the Armenians from Zeitun and the coast of the Gulf of Alexandretta as events that were decided on from case to case, even though they follow exactly the same logic-or rather, illogic-as the deportation orders set out in writing on May 27. Kaiser claims that "more carefully planned and coordinated deportations were not part of Ottoman government action at this point" and believes that this allows him to conclude that "this indicates that the decision for such a change of policy came about significantly later than many authors suspect." This is pure speculation. In fact, the differences between the deportations in February-March and those in May-June are minor.

Actually, one could say that a change in policy had already taken place several years earlier, when the leading Young Turks gave up their idea of a multinational country and began calling for a homogenous Turkish state. As early as 14 October 1910, Zitkovszky, the Austrian-Hungarian vice-consul in Monastir, reported to his foreign secretary, Aehrenthal, that Ottoman Home Secretary Talât had given a political speech in the secret circle of the Young Turk Committee in Thessaloniki, in which he had said the following:

You are aware that by the terms of the Constitution, equality of Muslim and Ghiaur was affirmed by you. One and all know and feel that this is an unrealizable ideal. The Sheriat and the history from the past oppose this, as do the feelings of hundreds of thousands of Muslims, and even the sentiments of the Ghiaurs themselves, who stubbornly resist every attempt to Ottomanize them, present an impenetrable barrier to the establishment of real equality. We have made unsuccessful attempts to convert the Ghiaur into a loyal Ottoman, and all such efforts must inevitably fail. ... . 24

In documents currently housed at the Archives of the French Foreign Office, the Austrian consul is identified as the best-informed man about the secret circles of the CUP. And Talât's long speech, reported by the French consul, was fully confirmed by Djavid, one of Talât's closest friends, who examined the paper three days later. ${ }^{25}$ There was to be no room in this unitary state for Christian minorities, and ultimately, the concept of Ottomanizing the empire was consolidated into a policy of annihilation. Djemal's deportations of the Armenians within his sphere of control were the beginning of the end of the Ottoman Armenians.

For Kaiser, the arrests and deportations of the Armenian elite from Constantinople on 24 April 1915 are not a reply to Van-where, after all, the Armenians took defensive action that was under military organization and successful for weeks-but to Zeitun. At least, "the Zeitun affair was given as one reason for the crack down" against the Armenians. ${ }^{26} \mathrm{He}$ lists orders given by Talât during the days right after April 24 to the most important provincial towns, in which allegedly dangerous Armenians were staying. 
Djemal was informed by Talât that the deportations from Zeitun to Konia had been stopped and the deportees were sent to Deir-es-Zor in the Syrian Desert; this suggests that a finalized and very definite plan already existed. Kaiser himself is forced to admit that

the order demonstrated that the central government asserted its leadership in the organization of deportations empire-wide, including the 4th Army's region. Talaat did not wait for Djemal's response and instructed the authorities at Adana, Aleppo, and Marash accordingly. ${ }^{27}$

Those Armenians who had been deported received very little assistance from the government. Kaiser reports that there were letters regarding financial aid that never materialized and writes, "In other words, the Armenian deportations would be disastrous and Ottoman authorities knew this from the moment they gave the orders." ${ }^{28}$ Aleppo Governor Djelal Bey, especially, had repeatedly requested exact information on the form and financing of a (supposedly planned) resettlement; except for promises, he never received anything. The offers from foreign organizations-for example, the American Red Cross-were, according to Kaiser, rejected on "political grounds." 29 While the houses the Armenians were forced to give up became available to Muslim refugees from the Balkans, it was not possible to procure any housing whatsoever for the Armenians. Whatever Djelal requested-and he was supported by Djemal-was, at best, answered by Talât with promises. However, according to Kaiser, "Talaat's promises for sufficient funding had not materialized." ${ }^{30}$

Kaiser writes, "The Ottoman defeat at Van marked a turning point after which the deportations were gradually transformed into a comprehensive policy to eliminate the Armenian community as a political force." ${ }^{31}$ Talât also sent Djemal a detailed plan of all those cities and regions from which the Armenians were deported, whereby "the Armenians were allowed to take along all of their movable property." 32 However, a "provisional law" was declared on 27 May 1915 and "details of the expropriations showed that the deportations were to create permanent changes in the demographic structure and that the deportations were not a temporary wartime measure as had been stipulated in the law."33

Kaiser reports on the alarming information passed on by the German consul in Aleppo, Walter Rössler, to his embassy and comments on it:

The reports by Rössler document a degree of cooperation with Djelal that went beyond the usual consular practice. The two men tried to mobilize the German embassy in order to lobby the Ottoman central government on behalf of the Armenians. At the same time, Rössler cooperated with Sahag, a leader of a community accused of treason. ${ }^{34}$

Was Sahag, the Catholicos of the Armenians in Cilicia, a traitor in Kaiser's eyes because he took care of his flock? Kaiser continues, "Obviously, both the consul and the governor entertained views on what needed to be done quite different from those prevalent in the capital." 35

During the ensuing period, Hilmar Kaiser quotes from letters written by Sahag to the German ambassador, Wangenheim, even though they were actually letters to the Armenian patriarch in Constantinople. The German consul in Adana, Büge, had had these letters sent via the embassy to the Armenian spiritual leader. ${ }^{36}$ There was, 
however, no conspiratorial connection between Armenians and top German politicians and diplomats in Constantinople, who continued to be on the side of the Young Turks, who were guilty of genocide. On the embassy's orders, letters from the catholicos to the patriarch were not even allowed to be transported by German couriers in the ensuing period without being opened. German censorship replaced that of the Young Turks. ${ }^{37}$ On July 26, the German embassy went even a step further in its refusal to send messages from the catholicos to the patriarch and simply returned an unopened letter from Sahag that had been passed on by Rössler. ${ }^{38}$

Kaiser writes that Djemal ordered that those Armenians who were deported because of their political beliefs were to be treated "correctly," whereby he refers once again not to Ottoman files, but to Djemal's orders, which had been passed on to the German authorities by Max von Oppenheim. ${ }^{39}$ According to these texts, Djemal had ordered that Armenians were to be treated according to their social position (leur position sociale); this leaves room for a great deal of interpretation. ${ }^{40}$ The fact that Kaiser does not quote any Ottoman documents appears to make it questionable whether the orders passed on by von Oppenheim were issued at all and whether they were ever followed.

Another unclear point in Kaiser's article is Djemal's request to send a particular official to Aleppo; Kaiser does not make clear what assignment this official was to carry out in Aleppo. However, there is an indication from Rössler that may possibly refer to the same person: "A particular official, Eyub Bey, has been sent to Aleppo to carry out the government's policies against Armenians. He reports directly to Fakri (Bey) Pasha," the German consul said in his telegram. "This effectively eliminates the governor, Djelal Bey; the government knows that he is in favor of a more lenient policy." 41

On the other hand, Kaiser gives the impression that the mild-mannered governor, Djelal, and the mild-mannered commanding officer, Djemal, were the best of friends; both advocated a more humane treatment of the Armenians. Eyub Bey, however, was a notorious annihilator of the Armenians, as proven by German sources. If Kaiser is referring to Eyub Bey when he speaks of the official, then the Armenian annihilator was at least subordinate to Fakhri Pasha and, therefore, Djemal.

Kaiser describes how Djemal attempted to inform Talât of the suffering of the Armenians and find money for them. In Aleppo, he ordered that five metallics be spent on adults and four on children. He referred to a report by Rössler dated 17 July 1915, who had listed the amounts in a single paragraph and remarked that, as a result of Djemal's order, the deported Armenians were able to rest somewhat in Aleppo. However, Rössler's report consists of a long list of atrocities that were carried out against the Armenians in Djemal's sphere of control. It ends with the following paragraph:

The Turkish government has driven its Armenian subjects-the innocent ones, mark you-into the desert in thousands upon thousands, under the pretext of having to remove them from the war areas, exempting neither the sick nor pregnant women nor the families of conscripted men, has given them both food and water in insufficient quantities and irregularly, has done nothing against the epidemics which have broken out amongst them, has driven the women to such desperation that they set out their babies and newborns by the wayside, has sold their adolescent daughters, with the result that they have thrown themselves even with their small children into the river. It has left them to the mercy of their guards and therefore to dishonor; an escort which dragged away the girls and sold them. It has driven them into the hands of the Bedouins, who have plundered and kidnapped 
them. It has had the men illegally shot in desolate places and the bodies of its victims fed to the dogs and birds of prey. It is supposed to have arranged for the murders of the representatives whom it had sent into exile. It has released prisoners from the prisons, put them in soldiers' uniforms and sent them to the areas where the deportees would be passing through. It has called up Circassian volunteers and set them onto the Armenians. ${ }^{42}$

Djemal had six of these Circassian murderers executed, as Kaiser proudly reports. Kaiser picks harmless sentences out of the German reports so as to give the impression that the foreign witnesses were covering up their euphemisms.

Kaiser's article becomes even stranger. He writes, "Rössler met with Djemal and reported positively on his talks." ${ }^{43}$ In note 94, Kaiser quotes as his source "Consulate of Aleppo, Package 1, Vol. 1/2, No. 1366, Rössler to Embassy, Aleppo, June 28, 1915, telegram 18." The text found in the consulate files goes as follows: "Have now repeatedly negotiated with Djemal Pasha. All of my assignments will be handled smoothly together with him. Will presumably travel south with Djemal in approx. eight days." This text was sent as telegram no. 18 to Constantinople on June 28 , but not to the embassy and, therefore, it is not in the files there. Kaiser has confused Rössler with Oppenheim, who had written this text. In the document quoted by Kaiser, Rössler had struck out the sender, "Oppenheim," and had written "Rössler" beneath it. Kaiser, the historian, was unable to interpret this event-or did not want to-because at the beginning of the text Rössler had clearly added in his own handwriting: "No. 18 dated June 28-from Baron Oppenheim.” The telegram was then sent to Oppenheim's office in Constantinople.

Kaiser then describes the deportations and killings that began to take place throughout the country, whereby he generally follows Rössler's reports and Djemal's orders in Oppenheim's report. ${ }^{44}$ Without doubt, the most important decision made by the government during this period was to recall the mild-mannered Djelal, of which Rössler informed his embassy in a telegram that is quoted by Kaiser, albeit once more in an abridged fashion:

Rössler cabled that Djelal would have to leave his post because of his refusal to deport Armenians from his province. Djelal had even guaranteed their good behaviour. Rössler suspected that the government wanted to have a free hand against the Armenians. ${ }^{45}$

However, Kaiser suppresses an addendum to the telegram. Rössler had noted, "This recall is regrettably not in Turkey's interest; presumably, the result will also be an escalation in the government's Arabic policy." ${ }^{\prime 6}$ Kaiser cites Rössler's handwritten note as the source on which his telegram was based. ${ }^{47}$ It includes not only the addendum regarding Arabic policy, but also Rössler's original sentence: "He [Djelal] had the opportunity to send a telegram to the government during the past few days, informing it that he did not approve of the actions against the Arabs in Beirut." It was, therefore, apparent that it was primarily Djelal's protest against Djemal's hard-line policy against the Arabs that resulted in his being recalled. In his article, Kaiser does not mention the Fourth Army's commanding officer's policy on Arabs anywhere at all.

Using Ottoman files, Kaiser describes in detail the purely statistical progress of the deportations. With regard to a description of the inhuman treatment of the deportees as well as the political consequences, he refers to Rössler's reports. ${ }^{48}$ Rössler had written 
that "it is becoming ever clearer that the orders for the harshest and most merciless implementation of the deportation decided on by the government must be put down to Fakhri Pasha and comes from him"-in other words, from Djemal's military assistant. ${ }^{49}$ However, Kaiser also hints several times at Fakhri's fatal role.

Kaiser argues that the fate of the deported Armenians proves the lack rather than the existence of an annihilation plan. As a consequence, the decision regarding the Armenians could not have been made in March, as some researchers claimed. Elements of planning were first cited in May and June as "a response to the ensuing chaos along the deportation routes and in the destination areas." He states that the deportations had not begun when the long-awaited opportunity presented itself, nor was a long-term program put into action. In his view, the CUP pushed the deportations without any previous planning or preparation. There was neither a monolithic CUP nor a dominating group on the committee.

Kaiser offers very little proof in his article for his antithesis. The behavior of Djemal and his officers could certainly have also been explained if the Committee for Union and Progress had already agreed at this time on a deportation plan. The Young Turks' fear that the Entente fleet would attempt to land in the Gulf of Alexandretta was understandable - the coastal strip was, in fact, without any defense whatsoever. Even the German consul in Adana had determined this to his great surprise and reported it to his embassy. The Entente's fleet was intact and on site; ships landed several times in those Ottoman harbors of the Mediterranean that had declared themselves free cities. Without doubt, the Armenian population in this region sympathized with the British and the French, but they were by no means prepared or in a position to provide military assistance. The Armenians may have been deported into the interior for reasons of extreme military caution, or following a decision that had been made to eradicate them. Therefore, Kaiser's conclusion is not substantiated.

At the beginning of the war, the situation for the Armenians within the sphere of control of the Fourth Army, of which Djemal was commanding officer, was somewhat worse than in the rest of the country, as shown by the actions taken against them. Towards the end of the war, the situation was reversed; apart from Constantinople and Smyrna, far more Armenians survived within Djemal's sphere of control than elsewhere in the Ottoman Empire. Western Syria, Lebanon, and Palestine were the only regions in which a relatively large number of Armenians (estimated at approximately 100,000150,000 people) survived the end of the war, albeit under the most severe conditions.

Kaiser believes that this is due to the resistance of the governor of Aleppo, Djelal, and to a lesser extent that of his successor, Bekir Sami, which is even more surprising since the latter described the Armenians as "microbes," thereby outing himself as a racist. Kaiser even speaks of a tacit agreement between these two and Rössler, without going into details. However, he presents Djemal Pasha as the chief resistance fighter. According to Kaiser,

If there ever was a secret CUP conference passing a decision on the deportations, CUP leader Ahmed Djemal had failed to learn about it.... He had his own ideas about settlement areas, the execution of deportations, the provisioning and reimbursement of deportees and, most importantly, also on their protection. Briefly put, he advocated some deportations and even initiated some others, but wanted to have them organized in a way that did not mean annihilation (of the Armenians). His orders for the protection of deportees were not empty words, as prominent 
CUP operatives found out when they were convicted by a 4th Army court martial and executed. ${ }^{50}$

Kaiser remarks that the honor of the Fourth Army demanded that the Armenians be resettled and Armenian villages set up. Djemal transmitted this to the governor of Syria Hulusi Bey, who immediately reported him to the central administration, thereby passing this on for future generations.

Kaiser writes that neither civilians nor the military in the Fourth Army determined that there were either revolts or a widespread conspiracy by or a dangerous threat from the Armenians. The leader of the army, Djemal, gave political or social reasons as grounds for the deportation programs, which were temporary and limited to the duration of the war. Either he was unaware of the long-term plans of the home secretary or he opposed them. Djemal knew exactly what was happening in other regions; he certainly did not prevent deportees from being sent to these regions. Kaiser writes that this must have led to their annihilation: "at times collaboration and resistance were close neighbours." ${ }^{1}$ According to Kaiser, the case of the Fourth Army "shows, however, that the notion of an empire-wide genocide of Ottoman Armenians perpetrated by a unified CUP is untenable. This kind of thinking needs to be revised and freed of claims that are based on imagination rather than evidence." 52

Until today, the only German historian who has seriously engaged himself with the Armenian Genocide-for which he was greatly admired-now argues against the theses of other researchers, but is not in a position to prove his own argument conclusively. He conceals severe atrocities committed by the Ottoman perpetrators, for example by Fakhri Pasha, who brutally suppressed alleged uprisings (e.g., in Urfa), and fantasizes about Western political powers who undertook less against the murderous frenzy of the Young Turks than the Fourth Army, even though he knows very well that the only Western power in Asia Minor that had military possibilities, namely Imperial Germany, was most definitely not prepared to do anything for the Armenians and permitted its own officers to drive Armenian civilians to their deaths.

There was a major difference between the age-old settlement areas of the Ottoman Armenians in northeastern Turkey and their settlements in the cities, and Djemal's sphere of control. There were hardly any Armenians in Palestine or even in the Lebanese mountains, which even today is still a center of Armenian life. The majority of the Armenians within Djemal's sphere of control came from Cilicia, the province around the city of Adana; Djemal was governor of this city before the war and had many old connections from that period.

While the Armenians in the northeast were mainly farmers and craftsmen in the towns, wealth was a characteristic of many of those Armenians in Cilicia and also in the west who were deported to Djemal's sphere of control. They had built up economically flourishing businesses and accumulated property. Their wealth was one of the keys to survival for many deportees, by giving "rescuers" a share of their companies, transferring ownership of their properties to public officials, providing money for bribes, or creating ties between Turkish and Armenian businessmen. Consul Hoffmann, who often represented Rössler, suspected that "the Armenian population of Aleppo seem to owe the fact that they are still here mainly to the resistance of those local circles who would suffer great financial losses if they disappeared." 53 However, these economic components do not appear at all in Kaiser's study, which only claims to identify "a definite historical connection." 
Djemal, who dreamed of building himself a long-term power base in Palestine and, if possible, Egypt, did a great deal to ensure that in future he would have wealthy and hard-working Armenians, namely those whose lives he had saved. He began by setting up Sahag, the catholicos who was expelled from his home in Cilicia, in Jerusalem and ensuring that, in accordance with the decree dated 30 July 1916, he became the catholicos-patriarch of all of the Armenians in the Ottoman Empire and resided in Jerusalem after the Young Turks dissolved the Constantinople patriarchate. In this way, he assured himself of the important spiritual leadership over the Armenians. Unfortunately, while preserving the lives of perhaps 150,000 Armenians-in terrible conditions-he helped kill another 150,000.

Instead of speaking of the opportunities missed by the Great Powers of the West to stop this genocide, Kaiser could have pointed out Djemal's attempts to use these Great Powers for his own interests. Raymond Kévorkian brought up the subject of secret discussions that were held between Djemal on the one hand and the French, British, and Russians on the other. In December 1915, Djemal informed his partners in these discussions that he was prepared to march to Constantinople with an army in order to dismiss the CUP and take over power himself, provided the Entente guaranteed the integrity of the Ottoman Empire, including Syria, Palestine, Mesopotamia, Arabia, Armenia, and Kurdistan, and, furthermore, provided it was prepared to make him the sultan with the right of succession for his descendents. In return, he would protect the Armenians and end the genocide. In the end, these discussions failed because of the fears of the French and the British that the Russians, who at that time had advanced as far as Trebizond and Erzerum, would use this opportunity to finally entrench themselves in Constantinople, for which they had been striving for a very long time. ${ }^{54}$

This was not the only aspect that Hilmar Kaiser completely ignored in his assessment of Djemal. What was inconsistent with his glorification of the good guy of Jerusalem was also the fanatical hatred with which Djemal persecuted the Arabs; he had begun to physically wipe out their elite.

It was not only the Arabs who trembled before Djemal, but the Jews and possibly other groups as well, as still unpublished German documents may show. One case was researched recently by German historian Michael Hesemann. At the beginning of 1917, the Palestine potentate had ordered the deportation of the Jews from Jaffa due to alleged collaboration with the British. Hesemann writes that

over 8,000 Jews were chased out of their houses without permission to take food or baggage with them. Their houses were looted by the Turks in front of their eyes. Two Jews were hanged at the gates of the Jewish suburb, as an example for anyone who dared to resist the looters. Eyewitnesses reported on the inhuman cruelty of the soldiers. Dozens of Jews were later found dead in the dunes of Jaffa. A dispatch from the Zionist office in Copenhagen ended by voicing the fear that after the threats from Djemal Pasha the Palestinian Jews could expect the same cruel fate as the Armenians: extermination by hunger, thirst and epidemics. ${ }^{55}$

At the beginning of December 1917, shortly before the British took Jerusalem, the Jews of that city were saved by German General von Falkenhayn, who received information through Eugenio Pacelli, the nuncio in Germany at that time who was to later become pope, and the Foreign Office. Jakob Thon, head of the Zionist office in Jerusalem at that time, wrote, 
It was a particular stroke of good fortune that General von Falkenhayn had supreme command during the last critical days. In this case, [Djemal] Pasha would have chased the population out of the entire region, as he had often threatened to do, and turned the country into ruins. Together with the entire rest of the population, both Christian and Muslim, we must be deeply grateful to P[acelli] who protected the civil population from demise by preventing the complete evacuation of this region as planned. ${ }^{56}$

It will still take a long time before we are fully clear on all the details of the Armenian Genocide after so much effort has been spent on manipulating it to make it disappear.

Wolfgang Gust, born in 1935 in Hannover, Germany, has served as correspondent, editor, and director of the German news magazine DER SPIEGEL for 30 years. He has published books and an expansive collection of German Foreign Office documents on the Armenian Genocide, which is available at www. armenocide.net.

\section{Notes}

1. Hilmar Kaiser, "Regional Resistance to Central Government Policies: Ahmed Djemal Pasha, the Governors of Aleppo, and Armenian Deportees in the Spring and Summer of 1915," Journal of Genocide Research 12,3-4 (2010): 173-218.

2. Wolfgang Gust, ed., Der Völkermord an den Armeniern 1915/16: Dokumente aus dem Politischen Archiv des deutschen Auswärtigen Amts (Hamburg: zu Klampen, 2005), Document 1915-03-07-DE-011. To access all of the documents on this genocide in the book, both in German and English, as well as more than 1,000 further files from the German and the Danish Foreign Offices, please visit www.armenocide. net.

3. Document 1916-01-03-DE-001, Appendix 1.

4. Kaiser, "Regional Resistance," 176.

5. Ibid.

6. Ibid.

7. Ibid.

8. Doc. 1915-03-07-DE-011.

9. Kaiser, "Regional Resistance," 177.

10. Doc. 1915-05-29-DE-001.

11. Kaiser, "Regional Resistance," 177.

12. Ibid.

13. Liman von Sanders, 20 June 1918, Politisches Archiv des Auswärtigen Amts (German Foreign Ministry Archives) [henceforth PA-AA], vol. R 1917.

14. 1914-10-16-DE-001; 1915-03-12-DE-001; 1915-03-18-DE-001; 1915-03-26-DE-001; 1915-03-26-DE-002; 1915-03-27-DE-011; 1915-03-29-DE-001; 1915-03-30-DE-001; 1915-03-30-DE-002; 1915-04-01-DE-001; 1915-04-12-DE-001; 1915-05-03-DE-011; 1915-05-27-DE-001.

15. Doc. 1915-04-26-DE-014.

16. Kaiser, "Regional Resistance,"179.

17. Ibid.

18. Ibid.

19. Ibid., 179-80.

20. Ibid., 180 .

21. Doc. 1915-08-29-DE-001.

22. Doc. 1915-08-29-DE-001.

23. Doc. 1916-01-03-DE 001, Appendix 1; remarks on Item 1: political and military reasons.

24. Doc. 1910-10-14-DE-001.

25. Turquie, Politique Intérieure, Dossier Général, tome 7, 1910, Série D, Carton 371, Archives of the French Foreign Office.

26. Kaiser, "Regional Resistance," 183.

27. Ibid.

28. Ibid., 184 .

29. Ibid. 
30. Ibid., 186 .

31. Ibid., 187.

32. Ibid.

33. To read the footnotes quoted by Kaiser, please visit www.armenocide.net (e.g., 73 (1915-06-26-DE-012); 74 (1915-06-03-DE-011); 75 and 76 (1915-06-06-DE-012); 77 (1915-06-09-DE-003) and 78 (to some extent 1915-06-12-DE-013).

34. Kaiser, "Regional Resistance," 189.

35. Ibid.

36. Doc. 1915-06-03-DE-002.

37. Doc. 1915-07-17-DE-004.

38. Doc. 1915-07-26-DE-002.

39. Doc. 1915-08-29-DE-001.

40. Ibid.

41. Doc. 1915-06-03-DE-011.

42. Doc. 1915-07-27-DE-001.

43. Kaiser, "Regional Resistance," 192.

44. Footnote 96: www.armenocide.net, Doc. 1915-07-17-DE-002 (already mentioned), Document 1915-0727-DE-001 as well as Document 1915-08-07-DE-001. Footnotes 97 and 98: 1915-08-29-DE-001.

45. Kaiser, "Regional Resistance," 193.

46. Doc. 1915-06-21-DE-013.

47. Footnote 101: Consulate of Aleppo, Package 1, Vol. 1, J. No. 1311, Telegram 9.

48. Footnotes 132 to 134 can be found on www.armenocide.net by entering the A numbers or B (consulate) numbers in the search window and searching for the documents from the corresponding years (the register numbers start from 1 again at the beginning of each year). The text from the consular file (no. 1657 ) is set out in Doc. 1915-07-30-DE-011, telegram 53 (this source is missing in Kaiser).

49. Doc. 1915-07-17-DE-002.

50. Kaiser, "Regional Resistance," 209.

51. Ibid., 210.

52. Ibid.

53. Doc. 1916-01-03-DE-001, Appendix 1.

54. Raymond Kévorkian, Le Génocide des Arméniens (Paris: Odile Jacob, 2006), 840ff.

55. Michael Hesemann, "Eugenio Pacelli und die Zionisten" [Eugenio Pacelli and the Zionists], Kathnews, 16 January 2011, http://kathnews.de/cms/cms/front_content.php?idart=857 (accessed 18 September 2012).

56. Microfilm K 1800 72/73, Central Zionist Archives, Jerusalem in Hesemann, "Eugenio Pacelli." 